\title{
Development of an electroporation procedure for gene disruption in Lactobacillus helveticus CNRZ 32
}

\author{
T. BHOWMIK and J. L. STEELE* \\ Department of Food Science, University of Wisconsin-Madison, 1605 Linden Drive, Madison, WI 53706, USA
}

(Received 17 November 1992; revised 24 February 1993; accepted 5 March 1993)

\begin{abstract}
An electroporation-mediated transformation method was developed and optimized for Lactobacillus helveticus CNRZ 32. The effects of electroporation buffers, growth conditions, cell-wall-weakening agents and field strength on transformation frequency were examined. Optimal conditions yielded a frequency of $2 \times 10^{4}$ transformants $(\mu \mathrm{g} \mathrm{pGK12})^{-1}$. Using this procedure, an integration plasmid was introduced into $L$. helveticus $\mathrm{CNRZ} 32$ to inactivate the chromosomal X-prolyl dipeptidyl aminopeptidase gene (pepXP). The integration plasmid, designated pSUW200, consisted of pUC19, the pE194 erythromycin resistance gene and a $1.6 \mathrm{~kb}$ internal fragment of the pepXP gene. The erythromycin resistance transformants obtained were $\mathrm{X}$-prolyl dipeptidyl aminopeptidase (XPDAP) negative. Southern hybridization results indicated that pSUW200 had integrated into the $\boldsymbol{L}$. helveticus CNRZ 32 chromosome via Campbell-type integration. After growth of the pSUW200-derived transformants for 112 generations under non-selective conditions, erythromycin-sensitive $\mathrm{X}-\mathrm{PDAP}^{+}$isolates were obtained. Southern hybridization results indicated that precise excision of pSUW200 had occurred via recombination between the $1.6 \mathrm{~kb}$ pepXP-derived nontandem repeats.
\end{abstract}

\section{Introduction}

Lactobacillus helveticus is an industrially important micro-organism which is used as a starter culture in the manufacture of a variety of fermented dairy products (Auclair \& Accolas, 1983), as a flavour adjunct capable of reducing bitterness and accelerating cheese flavour development (Bartels et al., 1987a,b), and is considered by some to be the organism of choice for the industrial production of lactate. However, understanding of the basic physiology and genetics of this organism is limited, due in part to the lack of modern molecular approaches for examining these organisms.

We have chosen to concentrate on L. helveticus CNRZ 32 because of its use as a cheese flavour adjunct (Bartels et al., $1987 a, b)$ and the availability of data concerning its proteolytic enzyme system (Khalid \& Marth, $1990 a, b$, 1991). The proteolytic enzyme system is thought to be responsible for this strain's ability to reduce bitterness and accelerate cheese flavour development. To date, we have constructed a gene bank of this organism in Escherichia coli and identified clones expressing six distinct peptidases (Nowakowski et al., 1993). The construction of isogenic derivatives of CNRZ 32, differing only in the activity of a single peptidase, would

*Author for correspondence. Tel. (608) 2625960 ; fax (608) 2626872. allow us to determine the impact of individual peptidases on this strain's ability to function as a flavour adjunct. Therefore, the objectives of this study were to develop an efficient electroporation-mediated transformation procedure for $L$. helveticus CNRZ 32, and to use this procedure to develop an approach, based on homologous recombination, for constructing isogenic derivatives of CNRZ 32.

\section{Methods}

Bacterial strains, growth conditions and plasmids. Bacterial strains and plasmids used in this study are listed in Table 1. L. helveticus strains were grown in MRS broth or agar (De Man et al., 1960) and Escherichia coli in LB broth or agar (Sambrook et al., 1989) at $37^{\circ} \mathrm{C}$. Erythromycin $(\mathrm{Em})$ and chloramphenicol $(\mathrm{Cm})$ were added at 4 and $7.5 \mu \mathrm{g} \mathrm{ml}^{-1}$ for L. helveticus and 1000 and $25 \mu \mathrm{g} \mathrm{ml}^{-1}$ for E. coli, respectively. Stock cultures were maintained at $-80^{\circ} \mathrm{C}$ and working cultures were prepared from frozen stocks through two transfers in MRS or LB broth for $L$. helveticus and $E$. coli, respectively.

Plasmid and chromosomal DNA isolation. Plasmid DNA was isolated from E. coli using alkaline lysis (Sambrook et al., 1989) and from lactobacilli using the procedure of Anderson \& McKay (1983). Preparative plasmid purification was conducted by $\mathrm{CsCl}_{2} / \mathrm{EtBr}$ density centrifugation (Sambrook et al., 1989). Chromosomal DNA was isolated from $L$. helveticus strains using the lysis procedure described by Anderson \& McKay (1983) and the extraction procedure described by Marmur (1961).

DNA manipulations. Restriction enzymes and T4 ligase were obtained from Bethesda Research Laboratory and used according to the 
Table 1. Bacterial strains and plasmids

\begin{tabular}{|c|c|c|}
\hline Strain or plasmid & Characteristics & Source/Reference \\
\hline L. helveticus CNRZ 32 & X-PDAP ${ }^{+}$, parental strain & Khalid \& Marth (1990) \\
\hline L. helveticus JLS 100 to 102 & $\begin{array}{l}\mathrm{Em}^{\mathrm{r}}, \mathrm{X}-\mathrm{PDAP} \\
\text { pep } \\
-\end{array}$ & This study \\
\hline L. helveticus JLS 100a & $\mathrm{Em}^{s}, \mathrm{X}-\mathrm{PDAP}^{+}$, derivative of JLS100 & This study \\
\hline E. coli $\mathrm{DH} 5 \alpha$ & 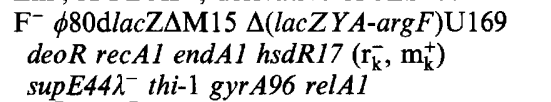 & BRL \\
\hline pGK 12 & $\mathrm{Em}^{\mathrm{R}}, \mathrm{Cm}^{\mathrm{R}}$ & Kok et al. (1984) \\
\hline pUC19E & $\begin{array}{l}\text { pUC19 containing Em gene of } \mathrm{pE} 194, \\
\mathrm{Amp}^{\mathrm{r}}, \mathrm{Em}^{\mathrm{r}}\end{array}$ & Leenhouts (1990) \\
\hline pSUW200 & $\begin{array}{l}\text { pUC19E containing an } 1.6 \mathrm{~kb} \text { pepXP } \\
\text { internal fragment, } \mathrm{Em}^{\mathrm{r}}, \mathrm{Amp}^{\mathrm{r}}, \mathrm{X}-\mathrm{PDAP}\end{array}$ & This study \\
\hline
\end{tabular}

manufacturer's instructions. Recombinant DNA techniques were carried out essentially as described by Sambrook et al. (1989).

Optimized electroporation procedure for L. helveticus. Electroporation was conducted using a Gene Pulser apparatus including a Pulse Controller unit (Bio Rad). The optimized procedure described below was developed by systematic analysis of the parameters described in this communication. A $1 \%$ inoculation from a working culture of $L$. helveticus CNRZ 32 was made into MRS broth containing $1 \%(\mathrm{w} / \mathrm{v})$ glycine (MRSG) and incubated at $37^{\circ} \mathrm{C}$ for $20 \mathrm{~h}$. This culture was used to inoculate $(1 \%, v / v) 250 \mathrm{ml}$ MRSG broth, with incubation at $37^{\circ} \mathrm{C}$ until $\mathrm{OD}_{600}=0 \cdot 25-0 \cdot 3$. Cells were harvested by centrifugation at $7520 \mathrm{~g}$ for $10 \mathrm{~min}$ at $4{ }^{\circ} \mathrm{C}$. Cells were washed four times with an equal volume of ice-cold electroporation buffer containing 0.1 mM-HEPES (Sigma) and $0.5 \mathrm{~m}$-sucrose (Ultra pure grade, BRL), $\mathrm{pH} 7.0$, and resuspended in $1.6 \mathrm{ml}$ electroporation buffer. The cell suspension $(800 \mu \mathrm{l})$ was mixed with $10 \mu \mathrm{l} \mathrm{pGK12}\left(100 \mathrm{ng}^{-1} \mathrm{l}^{-1}\right.$ dissolved in $10 \mathrm{mM}-$ Tris/HCl, $1 \mathrm{~mm}$-EDTA, $\mathrm{pH} 8.0$ ) and kept on ice for $5 \mathrm{~min}$. The mixture was then transferred into an electroporation cuvette $(0.40 \mathrm{~cm}$ interelectrode gap) and electroporated immediately using a single electric pulse. The electroporator settings were $2.5 \mathrm{kV}, 25 \mu \mathrm{F}$ and $200 \Omega$. After electroporation, the DNA/cell mixture was kept on ice for an additional $5 \mathrm{~min}$, diluted with $10 \mathrm{ml}$ MRS broth containing $10 \mathrm{mM}$ $\mathrm{CaCl}_{2}$, and incubated at $37^{\circ} \mathrm{C}$ for $3 \mathrm{~h}$. To determine the transformation frequency, cells were diluted, plated on $\mathrm{MRS} / \mathrm{CaCl}_{2}(10 \mathrm{~mm})$ agar containing the appropriate antibiotic, and incubated anaerobically (Becton Dickinson) for $72 \mathrm{~h}$ at $37^{\circ} \mathrm{C}$. Electroporations without the addition of pGK 12 served as the control.

Southern hybridization. Chromosomal DNA ( $4 \mu \mathrm{g}$ per lane) was digested with $S p h I$ and electrophoresed in 0.7\% agarose gels using Tris/acetate buffer (Sambrook et al., 1989). After electrophoresis, the DNA was transferred onto nylon membranes (Micron Separations) as described by Southern (1975), except the acid treatment was omitted. Preparation of probes, hybridizations and detections were carried out according to the manufacturer's instructions using the non-radioactive Genious kit (Boehringer Mannheim).

Integrant stability. To determine the stability of the $\mathrm{Em}^{\mathrm{r}}$ and X-prolyl dipeptidyl aminopeptidase negative $\left(\mathrm{X}^{\left.-\mathrm{PDAP}^{-}\right)}\right.$phenotypes, $L$. helveticus JLS100, JLS101, and JLS102 were grown in MRS broth without erythromycin. After 112 generations, cells were diluted and plated on media with and without Em. Additionally, 100 colonies were randomly picked from plates without Em to plates with and without $\mathrm{Em}$. The X-PDAP activity of colonies was determined by flooding plates with $5 \mathrm{ml}$ reaction mixture containing Gly-Pro- $\beta$-naphthylamide ( $2 \mathrm{mM}$ final concentration) dissolved in $N, N$ dimethyl formamide as described previously (Bhowmik \& Marth, 1990). In this assay, X-
$\mathrm{PDAP}^{+}$colonies stain red, while X-PDAP ${ }^{-}$colonies remain white Additionally, the chromosomal structure of a $\mathrm{Em}^{\mathrm{s}} \mathrm{X}-\mathrm{PDAP}^{+}$isolate was examined by Southern hybridization.

$X$-PDAP assay. The X-PDAP activity of broth cultures was assayed essentially as described previously (Bhowmik \& Marth, 1990), except that the cell suspension (approximately $10^{7}$ c.f.u. in $5 \mathrm{ml} 0.05 \mathrm{M}$ HEPES, pH 7.0) was permeabilized by mixing vigorously with $30 \mu \mathrm{l}$ chloroform for $1 \mathrm{~min}$.

All buffers and chemicals were reagent grade and purchased from Sigma unless otherwise indicated.

\section{Results}

The effects of several parameters on the electrotransformation frequency were systematically examined and the results are summarized as follows.

\section{Effect of electroporation buffers}

Cells were grown in MRS broth to $\mathrm{OD}_{600}=0 \cdot 7$, harvested by centrifugation, washed four times with an equal volume of buffer, and electroporated using the parameters described earlier. The effect of several buffers on the transformation frequency of $L$. helveticus $\mathrm{CNRZ}$ 32 using pGK12 were examined (Table 2). Sucrose $(0.5 \mathrm{M})$ was used as an osmostabilizer in $1 \mathrm{mM}$-HEPES buffer, $\mathrm{pH} \mathrm{7.0.} \mathrm{Use} \mathrm{of} 1 \mathrm{~mm}$-HEPES buffer, $\mathrm{pH} 7 \cdot 0$, gave the highest transformation frequency $\left(4 \times 10^{3}\right)$. Interestingly, the addition of $\mathrm{MgCl}_{2}$, a commonly used divalent cation in electroporation buffers, completely inhibited electrotransformation of $L$. helveticus CNRZ 32.

\section{Effect of growth media}

To determine the effect of growth medium, cells were grown in APT broth (Difco), Selective Lactobacilli (SL) broth (Difco), MRS broth containing no phosphate salt (MRSNP) and MRS broth containing $1 \mathrm{mM}-\mathrm{CaCl}_{2}$ (MRSC) to $\mathrm{OD}_{600} \simeq 0.7$. Cells grown in MRS broth 
Table 2. Effect of different buffers on electroporation frequency

MRS-grown cells were used. Gene Pulser settings: $2.5 \mathrm{kV}, 25 \mu \mathrm{F}$ and $200 \Omega$. Transformants were selected on MRS plates containing Cm $\left(7.5 \mu \mathrm{g} \mathrm{m}^{-1}\right)$.

\begin{tabular}{|c|c|}
\hline Buffers & $\begin{array}{c}\text { Transformants per } \\
\mu \mathrm{g} \text { pGK } 12\end{array}$ \\
\hline $\operatorname{SMEB}(3.5 \times)^{*}$ & $<1 \times 10^{2}$ \\
\hline $\mathrm{EPB} \oplus$ & $<1 \times 10^{2}$ \\
\hline HEPES $\ddagger$ & $4 \times 10^{3}$ \\
\hline HEPES + EDTA (1 mM) & $4 \times 10^{3}$ \\
\hline $\mathrm{HEPES}+\mathrm{CaCl}_{2}(1 \mathrm{~mm})$ & $3 \times 10^{3}$ \\
\hline $\mathrm{HEPES}+\mathrm{MgCl}_{2}(1 \mathrm{mM})$ & $<1 \times 10^{2}$ \\
\hline HEPES + Lysozyme & $<1 \times 10^{2}$ \\
\hline
\end{tabular}

* Sucrose magnesium electroporation buffer (Luchansky et al., 1988).

$\dagger$ Electroporation buffer (Powell et al., 1988).

$\ddagger$ HEPES ( $1 \mathrm{mM}$ ) buffer, containing 0.5 M sucrose, $\mathrm{pH} 7.0$.

$\S$ Final concentration, $2 \mathrm{kU} \mathrm{ml}^{-1}$ (Powell et al., 1988).

served as a control. Cells were then washed four times with $1 \mathrm{mM}$-HEPES buffer, $\mathrm{pH} 7 \cdot 0$ and electroporated as above. Transformation frequencies with MRS, MRSC, SL, APT and MRSNP broth were $4 \times 10^{3}, 2.5 \times 10^{3}$, $8 \times 10^{2}, 2 \times 10^{2}$, and $1 \times 10^{2}$, respectively. Therefore MRS broth was used throughout this study unless otherwise indicated.

\section{Effect of cell-wall-weakening agents}

The effect on transformation frequency of adding cellwall-weakening agents to MRS broth was investigated. In this instance, cells were grown to $\mathrm{OD}_{600}=0 \cdot 25-0 \cdot 30$. Cells were then harvested, washed and electroporated as described above. Cells were also grown in unsupplemented MRS as a control. The transformation frequencies observed with MRS, MRS supplemented with glycine $(1 \%$, w/v), MRS supplemented with DLthreonine ( $40 \mathrm{mM})$ and MRS supplemented with lysine $(40 \mathrm{~mm})$ were $4.3 \times 10^{3}, 6 \times 10^{3}, 4 \times 10^{3}$ and $1.2 \times 10^{3}$, respectively. No transformants were observed using MRS broth supplemented with 200 mM-DL-threonine. Addition of glycine $(1 \%, w / v)$ resulted in a slightly higher transformation frequency $\left(6 \times 10^{3}\right)$ compared to that of the control and other agents examined. Therefore MRS broth supplemented with $1 \%$ glycine (MRSG) was used routinely.

\section{Effect of growth phase}

To examine the effect of growth phase on transformation frequency, samples were taken at predetermined intervals from an MRSG broth culture, and were washed and electroporated as described above. The highest transformation frequency $\left(6 \times 10^{3}\right)$ was obtained in the early

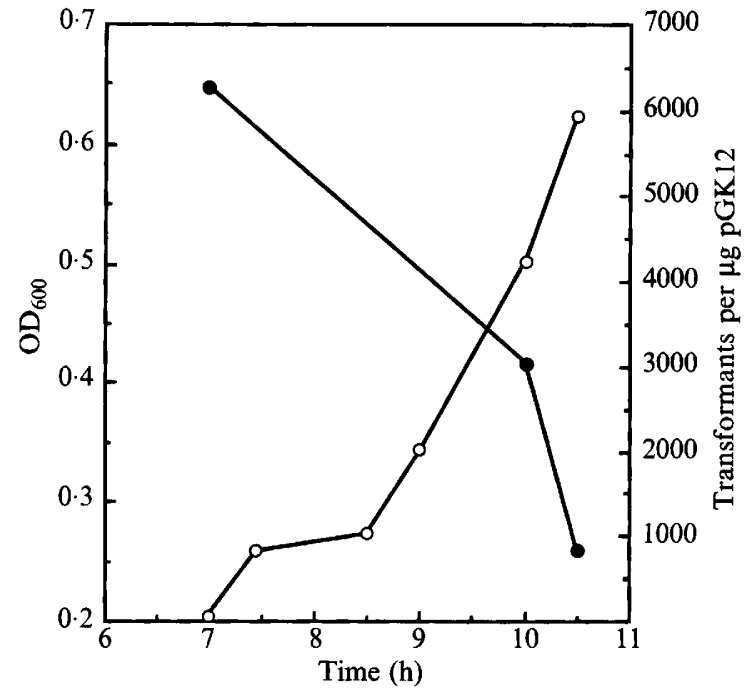

Fig. 1. Effect of growth phase on transformation frequency of MRSGgrown $L$. helveticus CNRZ 32. O, Transformants per $\mu \mathrm{g}$ pGK12, selected on MRS plates containing $\mathrm{Cm}\left(7.5 \mu \mathrm{g} \mathrm{ml}^{-1}\right) ; \bigcirc, \mathrm{OD}_{600}$.

exponential growth phase $\left(\mathrm{OD}_{600}=0 \cdot 25\right)$, after which time electroporation frequency decreased (Fig. 1). A similar pattern was observed when unsupplemented MRS broth was used as the growth medium; however, the overall electroporation frequency was lower (data not shown).

\section{Effect of $p H$ of HEPES buffer}

To determine the effect of buffer $\mathrm{pH}$ on transformation frequency, MRSG-grown cells were washed and electroporated with HEPES buffer adjusted in the range $\mathrm{pH} 4 \cdot 0-8 \cdot 0$. No transformants were observed at $\mathrm{pH} 4 \cdot 0$. Transformation frequencies at $\mathrm{pHs} 5 \cdot 0,6 \cdot 0,7 \cdot 0$ and $8 \cdot 0$ were $1.5 \times 10^{3}, 4.1 \times 10^{3}, 7.5 \times 10^{3}$ and $3.7 \times 10^{3}$, respectively. Therefore subsequent trials used HEPES buffer, $\mathrm{pH} 7 \cdot 0$.

\section{Effect of buffer strength}

To examine the effect of buffer strength, cells grown in MRSG broth were washed with, and resuspended in, buffer containing various HEPES concentrations $(0.01$ to $1.5 \mathrm{~mm}), \mathrm{pH} 7 \cdot 0$. Transformation frequencies at $0.01,0.1$, $0.5,1.0$ and $1.5 \mathrm{mM}$ were $3.8 \times 10^{3}, 2.0 \times 10^{4}, 6.9 \times 10^{3}$, $7.4 \times 10^{3}$ and $4.0 \times 10^{3}$, respectively. Therefore HEPES buffer was used at $0 \cdot 10 \mathrm{~mm}$ in subsequent trials.

\section{Effect of field strength}

To determine the effect of field strength on transformation frequency, cells were grown in MRSG broth, washed with HEPES (0.10 mM) buffer, $\mathrm{pH} 7.0$ and 

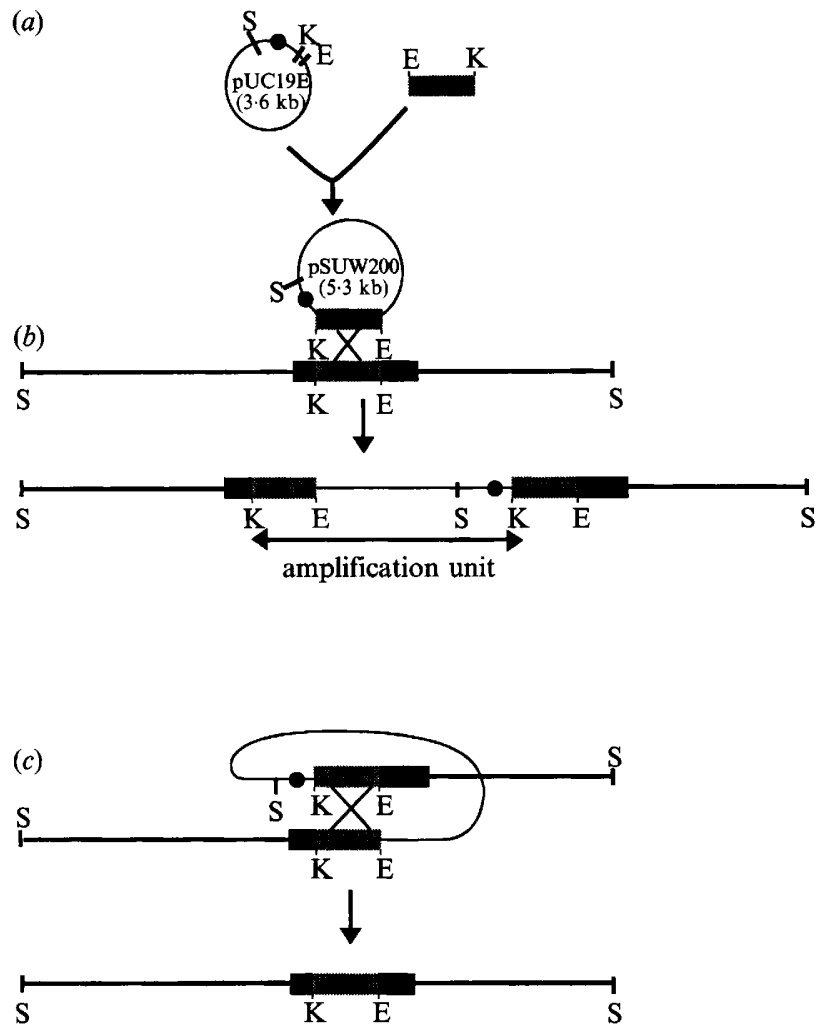

Fig. 2. (a) Construction of pSUW200. (b) pepXP gene disruption by Campbell-type integration. ( $c$ ) Recombination between the nontandem pepXP derived repeats, resulting in precise excision of pSUW200. 圆, Internal fragment of pepXP gene; $\square$, pep $X P$ gene; $\bullet$, erythromycin resistance gene; -, CNRZ 32 chromosomal DNA; -, pUC19; E, K and $\mathrm{S}$ represent restriction sites for $E c o \mathrm{RI}, K p n \mathrm{I}$, and $S p h \mathrm{I}$, respectively. Figure not drawn to scale.

electroporated in the same buffer. Transformation frequencies at field strengths of $4000,6250,8000$ and $12500 \mathrm{~V} \mathrm{~cm}^{-1}$ were $1.0 \times 10^{3}, 2.0 \times 10^{4}, 4.3 \times 10^{3}$ and $1.8 \times 10^{3}$, respectively. Therefore subsequent trials were done with a field strength of $6250 \mathrm{~V} \mathrm{~cm}^{-1}$.

\section{Inactivation of the L. helveticus CNRZ 32 pepXP gene}

To obtain an X-PDAP- derivative of $L$. helveticus CNRZ 32, an integration vector, designated pSUW200, was constructed (Fig. 2a). An internal $1.6 \mathrm{~kb}$ $E c o$ RI-KpnI fragment of the pepXP gene (Ünlü \& Steele; unpublished data) was cloned in pUC19E. This plasmid replicates in E. coli, but not in L. helveticus CNRZ 32, and expresses no detectable X-PDAP activity. The optimized electroporation procedure was used to introduce pSUW200 into L. helveticus CNRZ 32. In one experiment, three $\mathrm{Em}^{\mathrm{r}}$ transformants were obtained from $10 \mu \mathrm{g}$ of pSUW200 and designated JLS100-102. No transformants were obtained when electroporations were conducted using pUC19E. All three transformants were

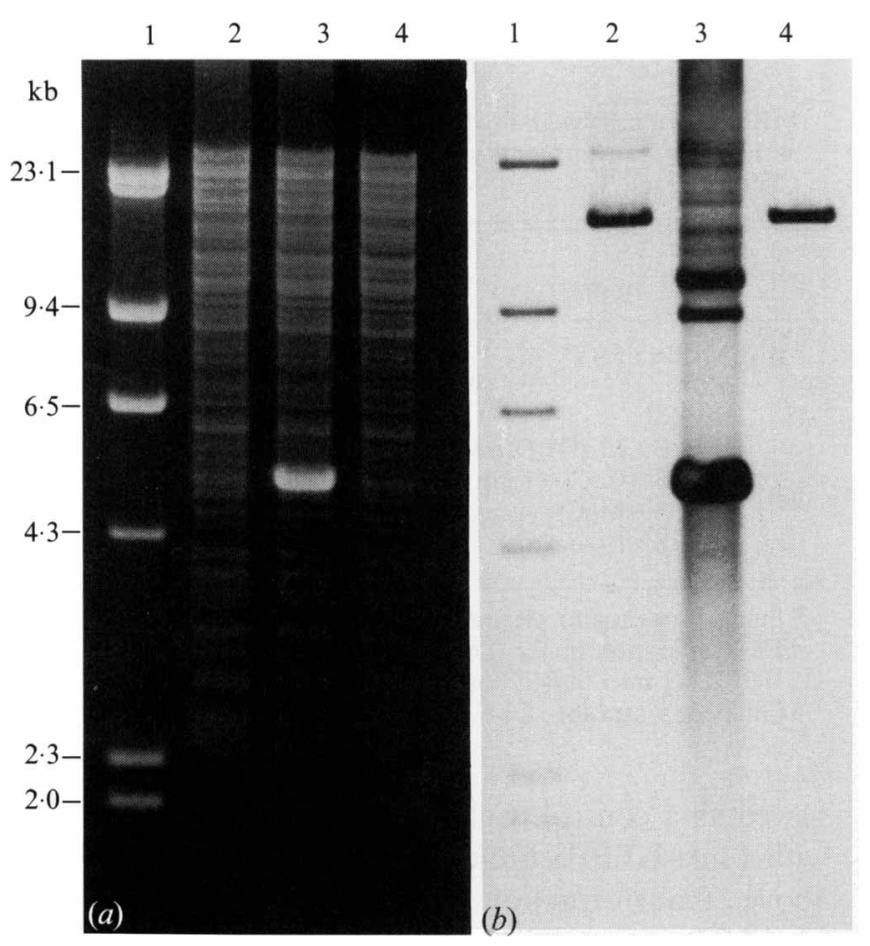

Fig. 3. Analysis of chromosomal structure by Southern hybridization. (a) Agarose gel electrophoresis of DNA samples. Lanes: $1, \lambda / H$ indIII molecular mass standards; 2, L. helveticus CNRZ 32 chromosomal DNA digested with SphI; 3, L. helveticus JLS100 chromosomal DNA digested with SphI; 4, L. helveticus JLS100a chromosomal DNA digested with SphI. (b) Southern hybridization of the gel shown in (a) with a probe synthesized from a $1.6 \mathrm{~kb} E c o \mathrm{RI}-K p n I$ internal fragment of pepXP.

determined to be X-PDAP ${ }^{-}$by the flood-plate and chloroform-permeabilized cell assays.

\section{Mechanism of chromosomal integration}

To determine the mechanism of integration of pSUW200, chromosomal DNA from $L$. helveticus CNRZ 32 and JLS100 was isolated, and analysed by Southern hybridization. Chromosomal DNA from both strains was digested with $S p h \mathrm{I}$ and hybridized with a probe synthesized from the $1.6 \mathrm{~kb} E c o \mathrm{RI}-K p n \mathrm{I} p e p X P$ internal fragment (Fig. 3). The pepXP probe hybridized with a $15.5 \mathrm{~kb} S p h \mathrm{I}$ chromosomal fragment of $L$. helveticus CNRZ 32 (Fig. $3 b$, lane 2). Bands of $10.5,8.8$ and $5.3 \mathrm{~kb}$ were observed in the JLS100 lane (Fig. 3b, lane 3). The $5.3 \mathrm{~kb}$ band was significantly more intense and corresponds in size with pSUW200. Similar results were obtained for JLS101 and JLS102 (data not shown).

\section{Stability of X-PDAP phenotype}

The stability of the X-PDAP ${ }^{-}$and $\mathrm{Em}^{\mathrm{r}}$ phenotypes of JLS100, JLS101 and JLS102 were determined and the results are presented in Table 3 . While $78-90 \%$ of 
Table 3. Stability of the Em phenotype after 112 generations under non-selective growth conditions

\begin{tabular}{lcc}
\hline \hline & \multicolumn{2}{c}{$\operatorname{Em}^{\text {r c.f.u. }(\%)^{*}}$} \\
\cline { 2 - 3 } Strain & Direct plating & With tooth picks \\
\hline CNRZ 32 & 0 & 0 \\
JLS100 & 13 & 17 \\
JLS101 & 97 & 78 \\
JLS102 & 87 & 84 \\
\hline \hline
\end{tabular}

* Values were determined by direct plating or picking individual colonies with tooth picks to media with and without erythromycin $\left(4 \mu \mathrm{g} \mathrm{ml}^{-1}\right)$.

JLS101 and JLS102 remained $\mathrm{Em}^{\mathrm{r}}$ after 112 generations under non-selective conditions, only $13-17 \%$ of the population of JLS100 remained $\mathrm{Em}^{\mathrm{r}}$. Regardless of the strain, all the $\mathrm{Em}^{\mathrm{r}}$ colonies examined were found to be XPDAP $^{-}$, while all the $\mathrm{Em}^{\mathrm{s}}$ colonies were X-PDAP ${ }^{+}$. The chromosomal structure of a $\mathrm{Em}^{\mathrm{s}} \mathrm{X}-\mathrm{PDAP}^{+}$revertant of JLS100, designated JLS100a, was examined via Southern hybridization using a probe synthesized from the $1.6 \mathrm{~kb}$ EcoRI-KpnI pepXP internal fragment. A single hybridizing band of $15.5 \mathrm{~kb}$, which was indistinguishable from the band detected in the CNRZ 32 lane, was detected in the JLS100a lane (Fig. 3b, lane 4).

\section{Discussion}

L. helveticus is an industrially important micro-organism which has received relatively little research attention. To apply modern molecular techniques to the study of this organism, an efficient genetic transformation system is required. Initially, we attempted to electrotransform $L$. helveticus CNRZ 32 with pGK12 using the procedures of Luchansky et al. (1988) and Powell et al. (1988); however, no transformants were obtained with either procedure. Therefore, the first objective of this study was the development of an efficient electrotransformation procedure for $L$. helveticus CNRZ 32.

The procedure optimized for CNRZ 32 yields $2 \times 10^{4}$ transformants per $\mu \mathrm{g}$ pGK12. The electroporation buffer system employed was determined to be the single most critical parameter examined. No transformants were obtained when buffer systems described by Luchansky et al. (1988) or Powell et al. (1988) were employed, whereas $4 \times 10^{3}$ transformants per $\mu \mathrm{g}$ pGK 12 were obtained using a HEPES buffer system. Optimization of other parameters such as growth media, growth phase, buffer $\mathrm{pH}$, buffer concentration, and field strength increased the frequency to $2 \times 10^{4}$ transformants per $\mu \mathrm{g} \mathrm{pGK} 12$. Recently, two other groups have reported electrotransformation of $L$. helveticus. Gavilan-Reyes et al. (1990) reported a frequency of $1.2 \times 10^{2}$ transformants per $\mu \mathrm{g}$ pGK12 with $L$. helveticus CNRZ 1340 using the procedure described by Luchansky et al. (1988). Recently the procedure developed by Hashiba et al. (1990) yielded $1.3 \times 10^{4}$ L. helveticus subsp. jugurti SBT2161C transformants per $\mu \mathrm{g}$ pLHR, a vector bsed on a cryptic plasmid from L. helveticus subsp. jugurti SBT2161. Because of the composition of the electroporation buffers employed in these procedures, it is unlikely that either of these approaches would yield transformants of $L$. helveticus CNRZ 32. Both electroporation buffers contain $1 \mathrm{mM}-\mathrm{MgCl}_{2}$, which we have demonstrated completely inhibits electroporation of CNRZ 32; additionally the buffer strength ( $7 \mathrm{mM}$ ) of both procedures was much higher than the buffer strength $(0.1 \mathrm{~mm})$ found to be optimal for CNRZ 32. These results indicate that there is significant variation between strains in the electroporation buffers required for electrotransformation in $L$. helveticus.

L. helveticus CNRZ 32 has been reported to enhance cheese flavour development; however the roles of individual gene products have not been examined, due to the lack of a procedure for constructing isogenic strains. Campbell-type integration of a nonreplicating plasmid is an approach that has been widely employed to construct isogenic strains differing in a single gene product. If the nonreplicating vector contains an internal fragment of the target gene, then a single cross-over event between the plasmid construct and the chromosome will result in two incomplete copies of the target gene, yielding a mutant deficient in the target gene product. This approach has been successfully applied in the construction of isogenic strains in Gram-positive bacteria such as Listeria monocytogenes (Wuenscher et al., 1991), Bacillus subtilis (Beall \& Lutkenhaus, 1989), Streptococcus mutans (Barletta et al., 1988; Hudson \& Curtiss, 1990) and Streptococcus pneumoniae (Berry et al., 1989). Since no homology was observed between pUC19E and chromosomal DNA of CNRZ 32 (data not shown), the pSUW200 $\mathrm{Em}^{\mathrm{r}}$ transformants most likely resulted from recombination between the internal pep $X P$ fragment of pSUW200 and the CNRZ 32 chromosomal pepXP. The X-PDAP ${ }^{-}$phenotype of the $\mathrm{Em}^{\mathrm{r}}$ transformants obtained, and the physical evidence provided by Southern hybridizations, strongly support this conclusion. Additionally, our results indicate that significant amplification of the integrated pSUW200 occurred. The expected product of Campbell-like integration, the vector flanked by regions of homology (Fig. $2 b$ ), is a structure known to be susceptible to amplification (Anderson \& Roth, 1977), and amplification of such structures has been observed in several other Gram-positive bacteria (Duncan et al., 1978; Niaudet et al., 1982; Young, 1983; Vosman et al., 1986; Chopin et al., 1989; Leenhouts et al., 1989, 1990). Therefore, the observed amplification of 
pSUW200 also implies that Campbell-like integration has occurred. To our knowledge, this is the first report of the construction of isogenic strains in lactobacilli via homologous recombination.

The structure produced by integration of pSUW200 into the CNRZ 32 chromosome was unstable during growth in the absence of selection for the pSUW200 $\mathrm{Em}^{\mathrm{r}}$ gene. Growth of two isolates without selection for $\mathrm{Em}^{\mathrm{r}}$ resulted in 3-13\% of the population becoming $\mathrm{Em}^{\mathrm{s}}$ after 112 generations; in the case of the third isolate, approximately $86 \%$ of the population was $\mathrm{Em}^{\mathrm{s}}$ after 112 generations. The variation in the stability of the $\mathrm{Em}^{\mathrm{r}}$ phenotype may reflect a difference in the extent of amplification of pSUW200 between the isolates. The results obtained by the direct plating of the culture on media with and without $\mathrm{Em}$ were similar to the results observed when colonies were transferred to media with and without Em. This differs from the results of Leenhouts et al. (1989) who observed a wide variation of the calculated stability obtained with these two methods. These authors hypothesized that the discrepancy between the two methods was the result of widely different levels of amplification of the integration plasmid within a culture. Southern analysis of a CNRZ-32-derived isolate which had lost the $\mathrm{Em}^{\mathrm{r}}$ phenotype, and the observation that $\mathrm{Em}^{\text {s }}$ colonies were X-PDAP ${ }^{+}$, suggests that precise excision of pSUW200 occurred via recombination between the nontandem pepXP-derived repeats (Fig. $2 c$ ). Precise excision via recombination between nontandem repeats produced via Campbell-like integration has been observed by other investigators (Chopin et al., 1989; Leenhouts et al., 1991).

In conclusion, an efficient method for electroporationmediated transformation of $L$. helveticus CNRZ 32 has been developed and used to construct an X-PDAP ${ }^{-}$ derivative of CNRZ 32 via Campbell-type integration. This approach should be useful in determining the contributions of individual components of the CNRZ 32 proteolytic enzyme system in the hydrolysis of casein.

This research was supported by a grant from the Wisconsin Milk Marketing Board. Additional support was provided by the College of Agricultural and Life Sciences of the University of Wisconsin-Madison. We thank Gülhan Ünlü for providing bacterial strains and DNA during this work.

\section{References}

ANDERSON, D. G. \& MCKAY, L. L. (1983). Simple and rapid method for isolating large plasmid DNA from lactic streptococci. Applied and Environmental Microbiology 46, 549-552.

ANDERSON, R. P. \& RoTH, J. R. (1977). Tandem genetic duplications in phage and bacteria. Annual Review of Genetics 31, 473-505.

AUClaIR, J. \& ACCOLAS, J. P. (1983). Use of thermophilic lactic starters in the dairy industry. Antonie Van Leeuwenhoek 49, 313-326.

Barletta, R. G., Michalek, S. M. \& CuRTiss, R., III. (1988). Analysis of the virulence of Streptococcus mutans serotype $c$ gtfA mutants in the rat model system. Infection and Immunity 56, 322-330.
Bartels, H. J., Johnson, M. E. \& Olson, N. F. (1987a). Accelerated ripening of Gouda cheese. 1. Effect of heat shocked thermophilic lactobacilli and streptococci on proteolysis and flavour development. Milchwissenschaft 42, 83-88.

Bartels, H. J., Johnson, M. E. \& Olson, N. F. (1987b). Accelerated ripening of Gouda cheese. 2. Effect of freeze-shocked Lactobacillus helveticus on proteolysis and flavor development. Milchwissenschaft 42, 139-144.

Beall, B. \& Lutkenhous, J. (1989). Nucleotide sequence and insertional inactivation of a Bacillus subtilis gene that affects cell division, sporulation and temperature sensitivity. Journal of Bacteriology 171, 6821-6834.

Berry, A. M., Yother, J., Briles, D. E., Hansman, D. \& Paton, J. C. (1989). Reduced virulence of a defined pneumolysin-negative mutants of Streptococcus pneumoniae. Infection and Immunity 57, 2037-2042.

Bhowmik, T. \& MARTh, E. H. (1990). Peptide-hydrolyzing enzymes of Pediococcus species. Microbios 62, 197-211.

Chopin, M. C., Chopin, A., Rouault, A. \& Galleron, N. (1989). Insertion and amplification of foreign genes in the Lactococcus lactis subsp. lactis chromosome. Applied and Environmental Microbiology 55, 1769-1774.

De Man, J., Rogosa, M. \& Sharpe, M. E. (1960). A medium for the cultivation of lactobacilli. Journal of Applied Bacteriology 23, 130-135.

DunCan, C. H., Wilson, G. A. \& Young, F. E. (1978). Mechanism of integrating foreign DNA during transformation of Bacillus subtilis. Proceedings of the National Academy of Sciences of the United States of America 75, 3664-3668.

Gavilan-Reyes, C. G., Limsowtin, G. K. Y., Sechaud, L., VeauX, M \& ACCOLAS, J. P. (1990). Evidence for a plasmid-linked restriction modification system in Lactobacillus helveticus. Applied and Environmental Microbiology 56, 3412-3419.

Hashiba, H., Takiguchi, R., Ish, S. \& Aoyama, K. (1990). Transformation of Lactobacillus helveticus subsp. jugurti with plasmid pLHR by electroporation. Agricultural and Biological Chemistry 54, 1537-1541.

Hudson, M. C. \& CURTISs, R., III. (1990). Regulation of expression of Streptococcus mutans genes important to virulence. Infection and Immunity 58, 464-470.

Khalid, M. N. \& Marth, E. H. (1990a). Purification and partial characterization of a prolyl-dipeptidyl aminopeptidase from Lactobacillus helveticus CNRZ 32. Applied and Environmental Microbiology 56, 381-388.

Khalid, M. N. \& MarTh, E. H. (1990b). Purification and partial characterization of an aminopeptidase from Lactobacillus helveticus CNRZ 32. Systematic and Applied Microbiology 13, 311-319.

Khalid, M. N. \& MarTh, E. H. (1991). Peptide hydrolases of Lactobacillus helveticus and Lactobacillus delbrueckii ssp. bulgaricus. Journal of Dairy Science 74, 29-45.

KoK, J., Van Der Vossen, J. M. B. M. \& Venema, G. (1984) Construction of plasmid cloning vectors for lactic streptococci which also replicate in Bacillus subtilis and Escherichia coli. Applied and Environmental Microbiology 48, 726-731.

Leenhouts, K. J., KoK, J. \& Venema, J. (1989). Campbell-like integration of heterologous plasmid DNA into the chromosome of Lactococcus lactis subsp. lactis. Applied and Environmental Microbiology 55, 394-400.

Leenhouts, K. J., KoK, J. \& Venema, G. (1990). Stability of the integrated plasmids in the chromosome of Lactococcus lactis. Applied and Environmental Microbiology 56, 2726-2735.

LeEnhouts, K. J., KoK, J. \& Venema, J. (1991). Replacement recombination in Lactococcus lactis. Applied and Environmental Microbiology 173, 47944798.

Luchansky, J. B., Muriana, P. M. \& Klaenhammer, T. R. (1988). Application of electroporation to transfer of plasmid DNA to Lactobacillus, Lactococcus, Leuconostoc, Listeria, Pediococcus, Bacillus, Staphylococcus, Enterococcus and Propionibacterium. Molecular Microbiology 2, 637-646.

MARMUR, J. (1961). A procedure for the isolation of deoxyribonucleic acid from micro-organisms. Journal of Molecular Biology 3, 208-218.

NiaUdet, B., Goze, A. \& ERLICH, S. D. (1982). Insertional mutagenesis 
in Bacillus subtilis: mechanism and use in gene cloning. Gene 19 , 277-284.

Nowakowski, C. M., Bhowmix, T. \& Steele, J. (1993). Cloning of peptidase genes from Lactobacillus helveticus CNRZ32. Applied Microbiology and Biotechnology 39, 204-210.

Powell, I. B., Achen, M. G., Hiller, A. J. \& Davidson, B. E. (1988). A simple and rapid method for genetic transformation of Lactic Streptococci by electroporation. Applied and Environmental Microbiology 54, 655-660.

Sambrook, J., Maniatis, T. \& Fritsch, E. F. (1989). Molecular Cloning: a Laboratory Manual. Cold Spring Harbor, NY: Cold Spring Harbor Laboratory.

SOUTHERN, E. M. (1975). Detection of specific sequences among DNA fragments separated by gel electrophoresis. Journal of Molecular Biology 98, 503-517.

Vosman, B., Kooistra, J., Olijve, J. \& Venema, J. (1986). Integration of vector-containing Bacillus subtilis chromosomal DNA by a Campbell-like mechanism. Molecular and General Genetics 204, 524-531.

Wuenscher, M., Kohler, S., Goebel, W. \& Chakraborty, T. (1991). Gene disruption by plasmid integration in Listeria monocytogenes: Insertional inactivation of the listeriosin determinant lis A. Molecular and General Genetics 228, 177-182.

YounG, M. (1983). The mechanism of insertion of a segment of heterologous DNA into the chromosome of Bacillus subtilis. Journal of General Microbiology 129, 1497-1512. 